\title{
Six new species of coccidia (Apicomplexa: Eimeriidae) from endangered Phelsuma spp. geckoes (Sauria: Gekkonidae) of the Black River Gorges National Park, Mauritius
}

\author{
Peter Daszak $^{1}$, Stanley J. Ball ${ }^{2}$, Carl G. Jones ${ }^{3}$, Daniel G. Streicker ${ }^{1,4}$ and Keith R. Snow \\ ${ }^{1}$ Wildlife Trust, 460 West 34th Street, 17th Floor, New York, NY 10001, USA; \\ ${ }^{2}$ School of Life Sciences, Kingston University, Kingston-upon-Thames, Surrey KTI 2EE, UK; \\ ${ }^{3}$ Mauritian Wildlife Foundation, Black River, Mauritius, and Durrell Wildlife Conservation Trust, Les Augrès Manor, Trinity, Jer- \\ sey, Channel Islands, UK; \\ ${ }^{4}$ Current address: Institute of Ecology, University of Georgia, Athens, GA 30602, USA; \\ ${ }^{5}$ School of Health and Bioscience, University of East London, London, E15 4LZ, UK
}

\begin{abstract}
Six new species of coccidia are described from endangered Phelsuma spp. geckoes (Sauria: Gekkonidae) endemic to Mauritius, Indian Ocean. Five new species (3 Eimeria and 2 Isospora species) are described from Phelsuma rosagularis Vinson et Vinson; all lack a micropyle and an oocyst residuum, and all have a sporocyst residuum. Oocysts of Eimeria swinnertonae sp. n. are ellipsoidal, $22.2 \times 17.8(20.8-24.8 \times 16.8-18.4) \mu \mathrm{m}$; SI 1.25 ; polar granule absent. Sporocysts are ellipsoidal, $8.8 \times 7.0$ $(8.0-9.6 \times 6.4-8.0) \mu \mathrm{m}$; SI 1.3; Stieda body absent. Oocysts of Eimeria stebbinsi sp. n. are ellipsoidal, $17.4 \times 11.7(16.0-19.2 \times 11.2-$ 12.8) $\mu \mathrm{m}$; SI 1.5; polar granules present. Sporocysts are elongate-ellipsoidal, $7.7 \times 4.0(7.2-8.0 \times 3.2-5.6) \mu \mathrm{m}$; SI 1.9; Stieda body present. Oocysts of Eimeria raleighi sp. n. are spheroidal to sub-spheroidal, $17.0 \times 15.5(16.0-19.2 \times 14.4-16.8) \mu \mathrm{m}$; SI 1.1; polar granule present. Sporocysts are sub-spheroidal, $7.8 \times 6.6(7.2-8.0 \times 6.4-7.2) \mu \mathrm{m}$; SI 1.2; Stieda body absent. Oocysts of Isospora cottinghamae sp. n. are ellipsoidal, $19.8 \times 15.5(17.6-21.6 \times 14.4-17.6) \mu \mathrm{m}$; SI 1.3; polar granules present. Sporocysts are ellipsoidal, $10.8 \times 6.9(9.6-12.8 \times 6.4-8.0) \mu \mathrm{m}$; SI 1.6; Stieda body present. Oocysts of Isospora pearlae sp. n. are ellipsoidal, $16.0 \times 11.5$ $(15.2-17.6 \times 9.6-12.8) \mu \mathrm{m}$; SI 1.4; polar granule present. Sporocysts are ellipsoidal, $8.8 \times 5.4(8.0-9.6 \times 4.8-6.4) \mu \mathrm{m}$; SI 1.6; Stieda and substieda bodies present. One new Eimeria species is described from the blue-tailed day gecko, Phelsuma cepediana Merrem. Oocysts of Eimeria hartleyi sp. n. are sub-spheroidal to ellipsoidal, $18.2 \times 14.5(16.0-20.8 \times 13.6-16.0) \mu \mathrm{m}$; SI 1.26; polar granules present. Sporocysts are ellipsoidal to cylindroidal, $7.5 \times 5.3(6.4-8.0 \times 4.8-6.4) \mu \mathrm{m}$; SI 1.4; Stieda body present. We report the presence of tetrazoic spheroidal to sub-spheroidal oocysts or sporocysts $10.2 \times 8.5(9.9-10.4 \times 8.3-8.8) \mu \mathrm{m}$; SI 1.2 from an individual of $P$. cepediana. These oocysts or sporocysts are significantly larger than the Cryptosporidium species so far described from reptiles, and likely represent excretion of spuriously ingested sporocysts of a Sarcocystis or Adelina coccidian.
\end{abstract}

Key words: Coccidia, Apicomplexa, Eimeriidae, Eimeria, Isospora, Reptilia, Sauria, Gekkonidae, Phelsuma, Mauritius

Mauritius is a volcanic island in the Indian Ocean 800 kilometres east of Madagascar. The majority of its endemic flora and fauna has been extirpated by the introduction of exotic animals and plants during the last 350 years (Cheke 1987). Relict populations of many endemic species persist in small pockets of relatively pristine habitat in montane rain forests on mainland Mauritius and on a number of satellite islets (Cheke 1987). The Black River Gorges National Park is a protected area of montane forest in south-western Mauritius that supports populations of skinks and geckoes endemic to this region (Jones and Hartley 1995). The only previous publications concerning parasites of Mauritian reptile fauna reported no blood parasites from a small collection of blood smears from Round Island reptiles (Peirce 1984) and discussed the factors affecting parasite prevalence on insular reptiles (Daszak 1995). No coccidia have previously been described from any endemic Mauritian vertebrates and despite the large diversity of the genus Phelsuma Gray, 1825 (over 60 taxa) only six coccidians have been described from this genus (Upton and Barnard 1987, Daszak and Ball 1991, Ball and Daszak 1995, Modrý et al. 1997). The current paper describes six new species of coccidia collected from Phelsuma geckoes endemic to south-western Mauritius as part of a survey of parasite biodiversity in these endangered species. 


\section{MATERIALS AND METHODS}

Geckoes were wild-caught during an expedition to Mauritius in October and November 1995 and housed individually in containers immediately after capture and up to the point of collection of faeces, except for seven individuals of Phelsuma cepediana Merrem which were housed together for 14 days in a vivarium at the Mauritius Wildlife Fund headquarters at Black River and faecal samples from these were pooled. Faecal samples from P. rosagularis Vinson et Vinson were collected four weeks after capture of the individual, following its importation into the UK. Faecal samples were placed in $2.5 \%$ potassium dichromate solution and examined by direct, wet mounts. Oocysts were measured and photographed under oil on a Zeiss photomicroscope III using Nomarski differential interference contrast optics. Mean oocyst lengths and widths are given with standard deviations and ranges in parentheses with all measurements in micrometres. Due to the rarity of the host animals and permit restrictions, no individuals were euthanized for examination of endogenous development of the coccidia described herein and no specimens were available for deposition as symbiotypes (Frey et al. 1992). Given the distinctive morphology of each gecko species on Mauritius, hosts were identified by morphological characteristics. Tail-clips from each individual were submitted for DNA sequencing, and identity was subsequently confirmed (M. Webster, E.N. Arnold, pers. comm.). For host species, we have followed the revised taxonomy of the Phelsuma proposed recently (Austin et al. 2004). Where prevalence data are given, the source of the sample and, if from captive animals, the length of time in captivity are indicated.

The oocyst morphology and measurements for the species described in the current paper have been compared with all coccidia previously described from the Gekkonidae. The etymology of specific names follows the tradition of naming endemic Mauritian wildlife for scientists, naturalists and conservation biologists.

\section{RESULTS}

\section{Apicomplexa: Eimeriidae}

\section{Eimeria swinnertonae sp. n.}

Figs. 1, 9

Description: Oocysts ellipsoidal, $22.2 \pm 1.1 \times$ $17.8 \pm 0.48(20.8-24.8 \times 16.8-18.4), \mathrm{n}=20$; shape index (length: width ratio, SI) $=1.25(1.14-1.38)$. Double-layered wall, outer approximately 0.8 thick and pale brown in colour; inner 0.7 and translucent. Micropyle, oocyst residuum and polar granules absent. Sporocysts ellipsoidal, $8.8 \times 7.0(8.0-9.6 \times 6.4-8.0) \mathrm{n}=20 ; \mathrm{SI}=1.26(1.10$ 1.37). Stieda body absent. Sporocyst residuum present, composed of scattered granules. Slight thickening present at the sporocyst pole, which may represent a projection of the longitudinal suture.

Type host: Phelsuma rosagularis Vinson et Vinson, 1969, the Mauritius upland forest gecko (Sauria: Gekkonidae). Adult male collected 21st October, 1995.

Type locality: Brise Fer Mountain, Black River Gorges National Park, Mauritius $\left(20^{\circ} 22^{\prime} 30^{\prime \prime} \mathrm{S}, 57^{\circ} 25^{\prime} 42^{\prime \prime} \mathrm{E}\right)$.

Site of infection: Unknown; oocysts recovered from faeces.
Prevalence: Two of four individuals. All five of the new species described in this paper were isolated from a single individual.

Type material: Photosyntype (Duszynski 1999) deposited at the Pathology Museum of the Institute of Zoology, Zoological Society of London, Regent's Park NWI 4RY, UK (Acc. No. ZSL002).

Et y m o logy: The specific name is given in honour of Kirsty Swinnerton of the Mauritius Wildlife Fund, who has been instrumental in ensuring the success of the in situ captive breeding programme for endangered Mauritian avian endemics.

Remarks. There is increasing support from morphological and molecular studies for the recently proposed genera Choleoeimeria Paperna et Landsberg, 1989 and Acroeimeria Paperna et Landsberg, 1989 as distinct groups of eimerian coccidia in lizards (Paperna and Landsberg 1989, Jirků et al. 2002, Modrý and Jirků 2006). Studies have further shown that each genus has distinct oocyst and sporocyst characteristics. However, designation of a species to either genus requires examination of the endogenous stages or molecular studies, and we therefore tentatively assign this and all other eimerian coccidia named in the current paper to the genus Eimeria until these details are reported. The oocysts of E. swinnertonae are larger than the other three Eimeria spp. described in this paper, with no overlapping in length or width ranges. Of the three previously described Eimeria species from the genus Phelsuma, oocysts of Eimeria phelsumae Daszak et Ball, 1991 are cylindroidal; oocysts of Eimeria simonkingi Ball et Daszak, 1995 are spheroidal to sub-spheroidal with more elongate sporocysts (SI 1.77); and oocysts of Eimeria brygooi Upton et Barnard, 1987 are spheroidal to sub-spheroidal (SI 1.1), with a colourless outer layer, are larger than E. swinnertonae, contain numerous small scattered granules and have ovoidal sporocysts without a thickening at one end (Upton and Barnard 1987, Daszak and Ball 1991, Ball and Daszak 1995). Seven of the other Eimeria spp. described from the Gekkonidae are ellipsoidal and have some slight overlap in measurements with E. swinnertonae. Oocysts of Eimeria lineri McAllister, Upton et Freed, 1988 from the Mediterranean gecko Hemidactylus turcicus turcicus in Texas (also found in Europe) are consistently larger; are more elongate with minimal overlap in width; usually have one, two or three polar granules; and have larger sporocysts which contain a more compact residuum than E. swinnertonae (McAllister et al. 1988). Oocysts of Eimeria telfordi Bovee, 1971, from Gehyra mutilata of Amami Island, Japan are less elongate (SI 1.21), have a thin wall $(0.8-1.0)$ that is usually single with a very thin outer layer sometimes visible, and have sporocysts that are more sub-spheroidal (SI 1.14) than those of E. swinnertonae (Bovee 1971). Oocysts of Eimeria cicaki Else et Colley, 1975 from Gehyra mutilata and Hemidactylus frenatus in Malaysia are less elongate (SI 1.13) than those of E. swinnertonae, with minimal 

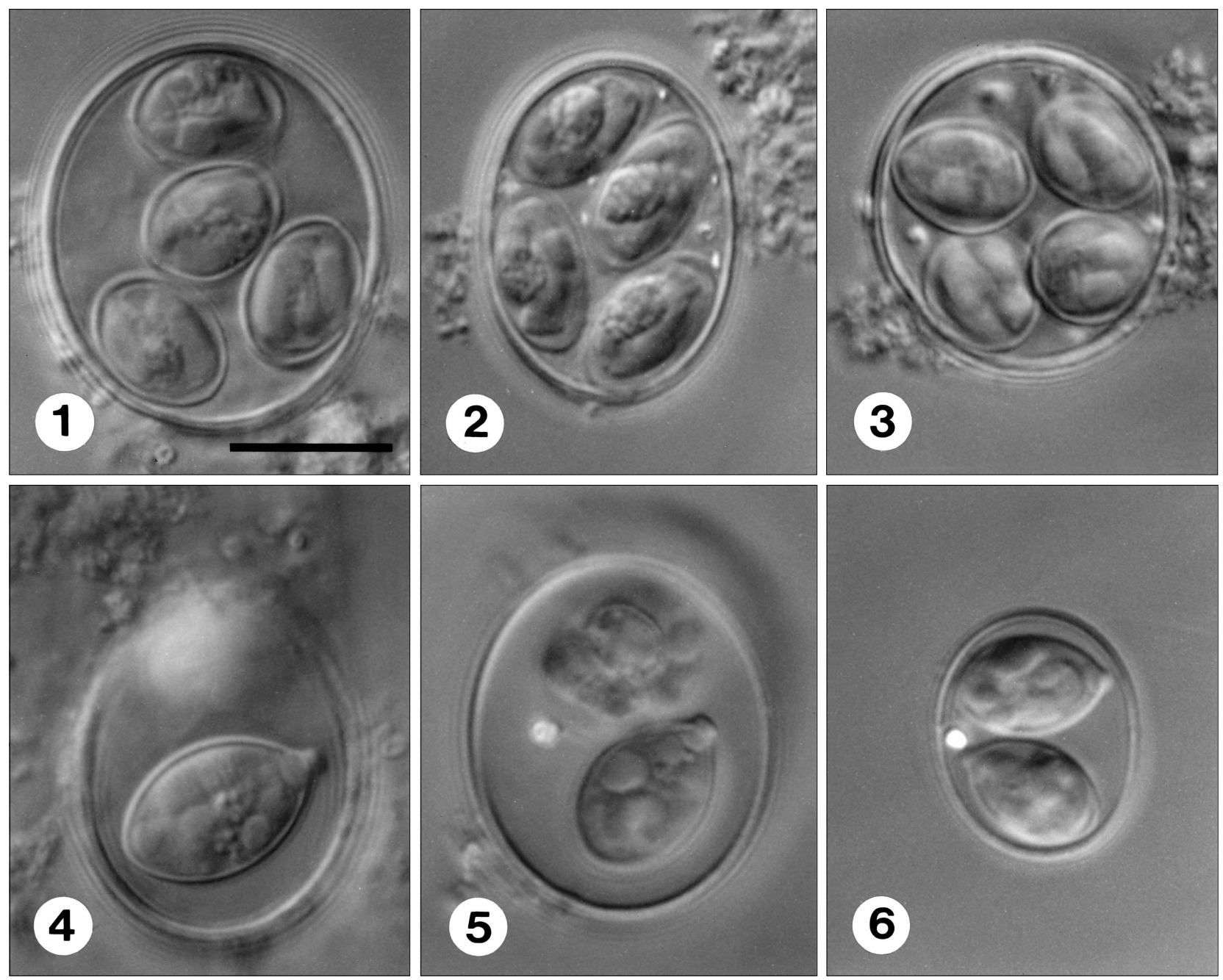

Figs. 1-6. Nomarski differential interference contrast photomicrographs of sporulated oocysts of coccidian parasites from the faeces of Phelsuma rosagularis in the Black River Gorges National Park, Mauritius. Fig. 1. Eimeria swinnertonae sp. n. Fig. 2. Eimeria stebbinsi sp. n. Fig. 3. Eimeria raleighi sp. n. Figs. 4, 5. Isospora cottinghamae sp. n. Fig. 6. Isospora pearlae sp. n. Scale bar (for all figures) $=10 \mu \mathrm{m}$.

overlap in size range, and contain 3-7 polar granules. The sporocysts of E. cicaki are much larger and there is no overlap in size range with E. swinnertonae (Else and Colley 1975). Oocysts of Eimeria pachybibroni Upton, Freed et Burdick, 1992, from Pachydactylus bibroni bibroni in Namibia are more elongate (SI 1.44) than E. swinnertonae and contain polar granules and sub-spheroidal sporocysts (Upton et al. 1992a). Oocysts of Eimeria furmani Upton, Freed, Burdick et McAllister, 1990 from Hemidactylus frenatus in Madagascar are smaller, have a thinner outer wall and contain small and scattered fragments of polar granules, or have a single polar granule. In addition, the sporocysts are larger and more ellipsoidal (SI 1.33) than those of our second new eimerian, E. stebbinsi sp. n. described below. Finally, Eimeria barnardi Upton, Freed et Burdick 1992, from Rhoptropus barnardi in Namibia are larger, with scattered polar granules and larger sporocysts than E. swinnertonae (Upton et al. 1992a).

\section{Eimeria stebbinsi sp. n.}

Figs. 2, 10

Description: Oocysts ellipsoidal, $17.4 \pm 1.3 \times 11.7 \pm$ $1.3(16.0-19.2 \times 11.2-12.8), \mathrm{n}=10 ; \mathrm{SI}=1.5(1.25-1.7)$. Bilayered wall approximately 0.6 thick. Micropyle, oocyst residuum absent, 5-8 small polar granules scattered throughout oocyst. Sporocysts elongate ellipsoidal, $7.7 \times 4.0(7.2-8.0 \times 3.2-5.6), \mathrm{n}=10 ; \mathrm{SI}=1.9(1.43-$ 2.25). Stieda body absent. Sporocyst residuum present, composed of a spheroid deposit of globular material.

Type host: Phelsuma rosagularis Vinson et Vinson, 1969, the Mauritius upland forest gecko (Sauria: Gekkonidae). Adult male collected 21st October, 1995.

Type locality: Brise Fer Mountain, Black River Gorges National Park, Mauritius $\left(20^{\circ} 22^{\prime} 30^{\prime \prime} \mathrm{S}, 5^{\circ} 25^{\prime} 42^{\prime \prime} \mathrm{E}\right)$.

Site of infection: Unknown; oocysts recovered from faeces.

Prevalence: Two of four individuals. All five of the new 
species described in this paper were isolated from a single individual.

Type material: Photosyntype deposited at the Pathology Museum of the Institute of Zoology, Zoological Society of London, Regent's Park NWI 4RY, UK (Acc. No. ZSL003).

Ety mology: The specific name is given in honour of Cynthia and James Stebbins to recognise their enthusiastic support of conservation issues at home and around the world.

Remarks. The oocysts of E. stebbinsi are smaller than the three other Eimeria spp. described here, with no overlapping of size ranges. Eimeria stebbinsi can be distinguished from the three Eimeria spp. previously reported from Phelsuma spp. by its ellipsoidal oocysts: oocysts of E. phelsumae Daszak et Ball, 1991 are cylindroidal, and oocysts of Eimeria simonkingi Ball et Daszak, 1995 and Eimeria brygooi Upton et Barnard, 1987 are spheroidal to sub-spheroidal (Upton and Barnard 1987, McAllister et al. 1988, Daszak and Ball 1991, Ball and Daszak 1995). Oocysts of E. stebbinsi are distinguished from all other eimerian parasites of geckoes by their shape, size and presence of elongate ellipsoidal sporocysts.

\section{Eimeria raleighi sp. n.}

Figs. 3, 11

Description: Oocysts spheroidal to sub-spheroidal, $17.0 \pm 1.3 \times 15.5 \pm 0.6(16.0-19.2 \times 14.4-16.8), \mathrm{n}=10 ;$ $\mathrm{SI}=1.1(1.0-1.2)$. Bilayered wall approximately 0.7 thick with pale brown outer wall and clear inner wall of 0.5 . Micropyle, oocyst residuum absent, 2-4 polar granules scattered throughout oocyst. Sporocysts sub-spheroidal, $7.8 \times 6.6(7.2-8.0 \times 6.4-7.2), \mathrm{n}=10 ; \mathrm{SI}=1.2(1.0-1.25)$. Stieda body absent. Sporocyst residuum present, composed of fine granules.

Type host: Phelsuma rosagularis Vinson et Vinson, 1969, the Mauritius upland forest gecko (Sauria: Gekkonidae). Adult male collected 21st October, 1995.

Type locality: Brise Fer Mountain, Black River Gorges National Park, Mauritius $\left(20^{\circ} 22^{\prime} 30^{\prime \prime} \mathrm{S}, 5^{\circ} 25^{\prime} 42^{\prime \prime} \mathrm{E}\right)$.

Site of infection: Unknown; oocysts recovered from faeces.

Prevalence: Two of four individuals. All five of the new species described in this paper were isolated from a single individual.

Type material: Photosyntype deposited at the Pathology Museum of the Institute of Zoology, Zoological Society of London, Regent's Park NWI 4RY, UK (Acc. No. ZSL004).

Etymology: The specific name is given in honour of "Raleigh" (www.raleighinternational.org), a British youth development charity formerly known as "Raleigh International", which organises expeditions around the globe, promoting conservation and scientific field research in the best British tradition of international goodwill. Their 1993 expedition to Mauritius was the groundwork for the current study. The specific name here is the genitive of the surname of Sir Walter Raleigh, the English explorer, after whom the organisation 'Raleigh International' is named.
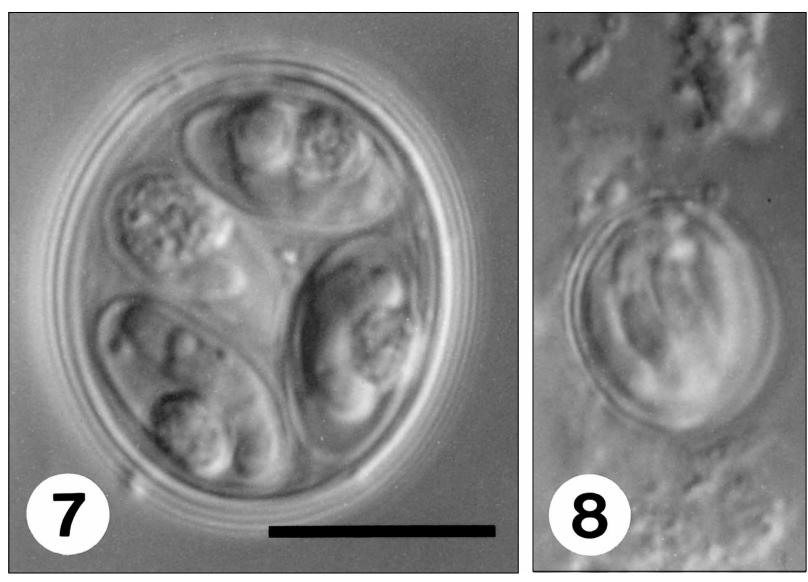

Figs. 7, 8. Nomarski differential interference contrast photomicrographs of sporulated oocysts of coccidian parasites from the faeces of Phelsuma cepediana in the Black River Gorges National Park, Mauritius. Fig. 7. Eimeria hartleyi sp. n. Fig. 8. Unidentified coccidian which most likely represents the sporocysts of an Adelina sp. ingested by the host. Scale bar (for both figures) $=10 \mu \mathrm{m}$.

Remarks. Oocysts of E. raleighi differ from those of the other Eimeria spp. described in the current paper in their shape and measurements. The measurements of their sporocysts are different from the three previously described Eimeria species reported from Phelsuma spp. (see remarks under E. swinnertonae). Oocysts of five other Eimeria spp. from the family Gekkonidae are spheroidal to sub-spheroidal and overlap slightly in measurement ranges with E. raleighi. The oocysts of Eimeria gekkonis Tanabe, 1928 from Gekko japonicus can be distinguished from $E$. raleighi by their ovoidal sporocysts with tapered ends, smaller oocyst dimensions, the possible presence of a micropyle, and the geographical and taxonomic distance of the host species from that of E. raleighi (Tanabe 1928). An Eimeria sp. reported from Hemidactylus frenatus of Formosa has larger oocysts than E. raleighi and was reported to possess a micropyle; however no drawings or details on the sporocyst morphology and dimensions were given (Yamamoto 1933). It has been proposed that Eimeria furmani Upton, Freed, Burdick et McAllister, 1990 represents this species (Upton et al. 1990). The oocysts of E. furmani are distinct from E. raleighi by their ellipsoidal shape, larger size, thicker wall, lack of a polar granule and larger sporocysts. Eimeria hemidactyli Knowles et Das Gupta, 1935 and Eimeria knowlesi Bhatia, 1936 from Hemidactylus flaviviridis in India have larger oocysts that differ in shape from E. raleighi (Knowles and Das Gupta 1935, Bhatia 1936). Eimeria boveroi McAllister et Upton, 1989, described from Hemidactylus mabouia in Mexico has larger oocysts which overlap only minimally in oocyst width with $E$. raleighi and only rarely contain a single polar granule, compared to the distinct scattered polar granules of E. raleighi (McAllister and Upton 1989). 

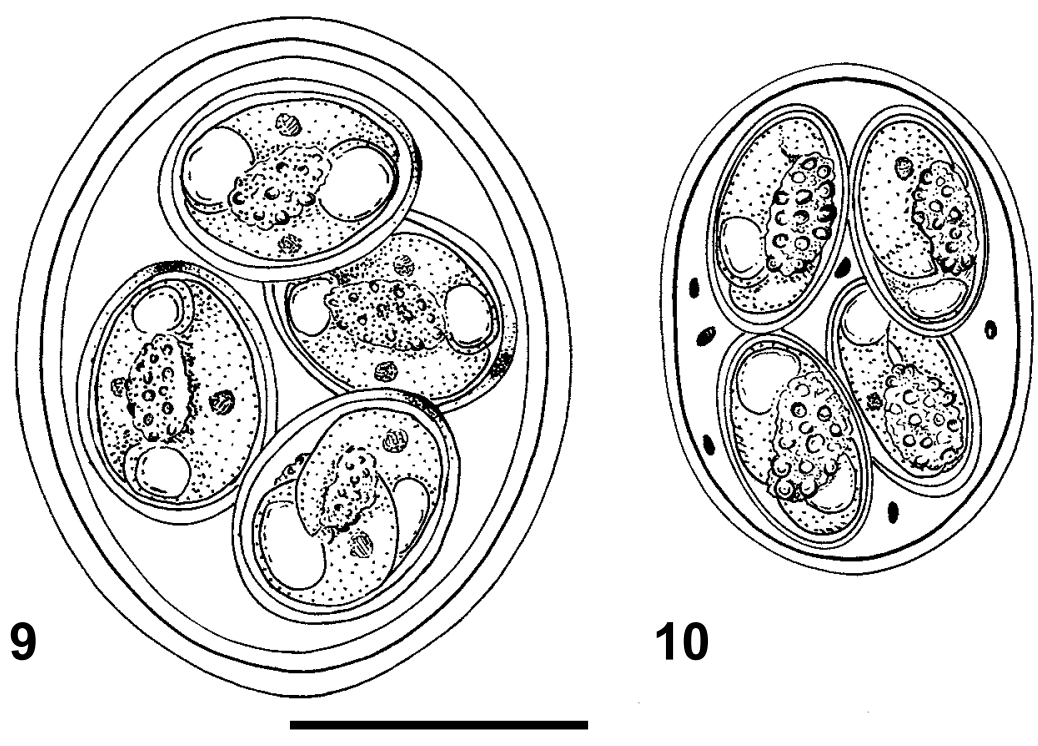

10

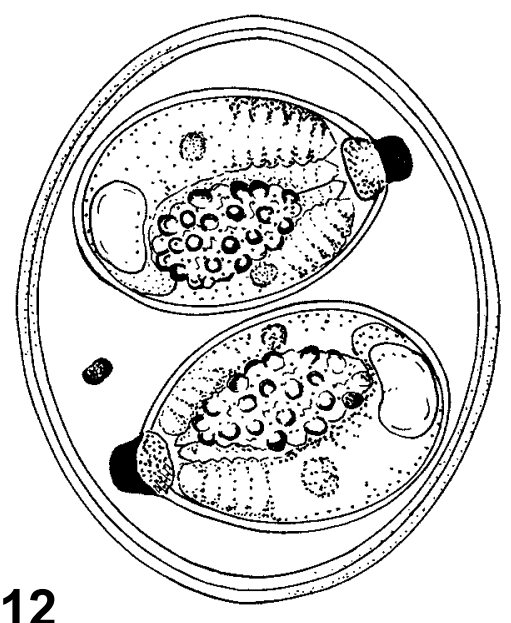

\section{0}

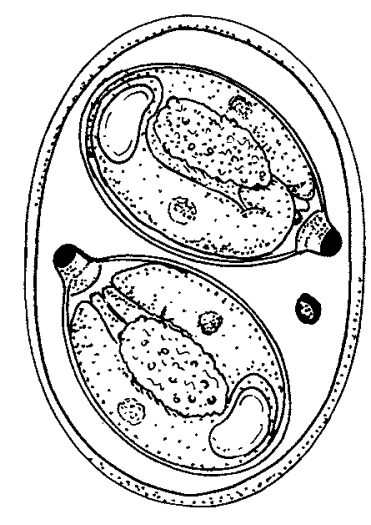

13

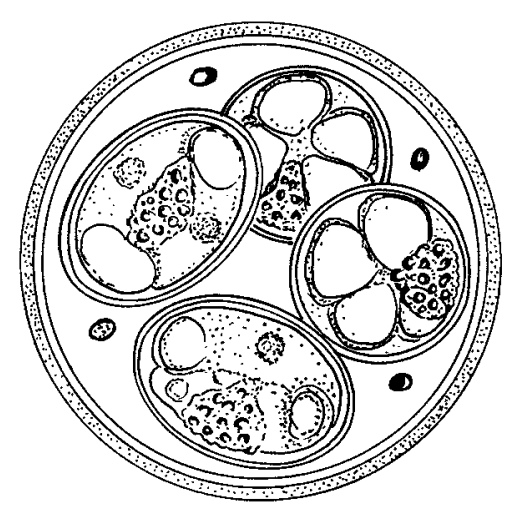

11

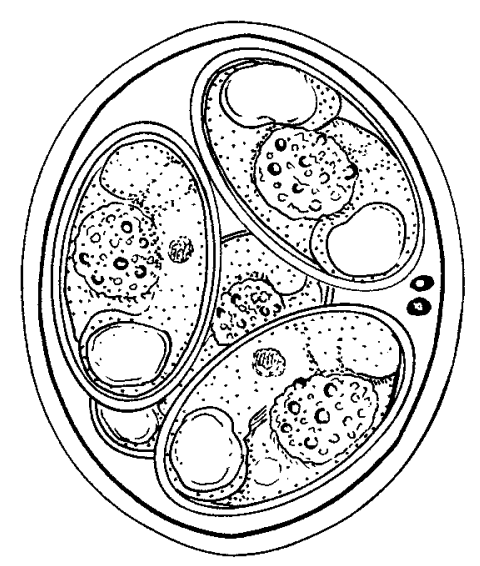

14

Figs. 9-14. Composite line drawings of sporulated oocysts of coccidian parasites from Mauritian Phelsuma spp. geckoes. Fig. 9. Eimeria swinnertonae sp. n. Fig. 10. Eimeria stebbinsi sp. n. Fig. 11. Eimeria raleighi sp. n. Fig. 12. Isospora cottinghamae sp. n. Fig. 13. Isospora pearlae sp. n. Fig. 14. Eimeria hartleyi sp. n. Scale bar (for all figures) $=10 \mu \mathrm{m}$.

\section{Isospora cottinghamae $\mathrm{sp} . \mathrm{n}$.}

Figs. $4,5,12$

Description: Oocysts ellipsoidal, $19.8 \pm 1.1 \times$ $15.5 \pm 0.96(17.6-21.6 \times 14.4-17.6), \mathrm{n}=20 ; \mathrm{SI}=1.3$ $(1.1-1.5)$. Bilayered wall approximately 0.8 thick. Micropyle and oocyst residuum absent, single large, prominent polar granule present. Sporocysts ellipsoidal, $10.8 \times 6.9$ $(9.6-12.8 \times 6.4-8.0), \mathrm{n}=20 ; \mathrm{SI}=1.6(1.3-2.0)$. Prominent, nipple-like Stieda body, substieda body present. Sporocyst residuum composed of many small granules loosely arranged. Anterior portion of sporozoites have folded appearance.

Type host: Phelsuma rosagularis Vinson et Vinson, 1969, the Mauritius upland forest gecko (Sauria: Gekkonidae). Adult male collected 21st October, 1995.

Type locality: Brise Fer Mountain, Black River Gorges

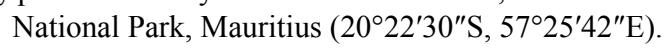

Site of infection: Unknown; oocysts recovered from faeces.

Prevalence: Two of four individuals. All five of the new species described in this paper were isolated from a single individual.

Type material: Photosyntype deposited at the Pathology Museum of the Institute of Zoology, Zoological Society of London, Regent's Park NWI 4RY, UK (Acc. No. ZSL005).

Etymology: The specific name is given in honour of Dr. Janet D. Cottingham, who located these elusive and retiring geckoes during the 1995 expedition.

Remarks. The oocysts of Isospora cottinghamae have a bilayered wall, are consistently larger, less elongate and have consistently larger sporocysts, with no overlap in size ranges, than those of I. pearlae sp. n. described below. Note that the ranges of the sporocyst and oocyst 
widths and lengths do not form a continuum with those of $I$. pearlae, and are distinct when presented as a scattergram of individual oocyst lengths vs. widths (data not shown). Of the three Isospora previously reported from the genus Phelsuma, oocysts of Isospora gekkonis Upton et Barnard, 1987 are spheroidal to sub-spheroidal and larger with no overlap in size ranges, oocysts of Isospora gardneri Modrý, Koudela et Volf, 1997 are ellipsoidal, but much larger without overlap in size ranges, and oocysts of Isospora ladiguensis Modrý, Koudela et Volf, 1997 are spheroidal to sub-spheroidal and do not overlap in size ranges with I. cottinghamae (Upton and Barnard 1987, Modrý et al. 1997). Among the additional 21 Isospora species known to infect gekkonid hosts, three have some overlap in size ranges with I. cottinghamae. Oocysts of I. schlegeli Upton, Hanley, Case et McAllister, 1991 from Hemidactylus frenatus and Lepidodactylus lugubris in the Philippines and Mariana Islands are smaller, more spheroidal $(\mathrm{SI}=1.13)$ and with ovoid sporocysts $(\mathrm{SI}=1.33)$ (Upton et al. 1991). Oocysts of I. cytoheteronotis Finkelman et Paperna, 2002, are spheroidal to sub-spheroidal $(\mathrm{SI}=1.00-1.24)$, larger than those of $I$. cottinghamae, contain larger ovoidal sporocysts and lack a polar granule (Finkelman and Paperna 2002). Oocysts of I. hemidactyli Carini, 1936 from Hemidactylus mabouia in Cameroon are larger, more spheroidal $(\mathrm{SI}=1.1)$ and contain larger, more spheroidal sporocysts $(\mathrm{SI}=1.24)$ than those of I. cottinghamae (Upton et al. 1992b).

\section{Isospora pearlae $\mathrm{sp} . \mathrm{n}$}

Figs. 6, 13

Description: Oocysts small, ellipsoidal, translucent, $16.0 \pm 0.62 \times 11.5 \pm 1.1(15.2-17.6 \times 9.6-12.8), \mathrm{n}=10$; $\mathrm{SI}=1.4(1.25-1.67)$. Single-layered wall approximately 0.4 thick. Micropyle and oocyst residuum absent, single polar granule present. Sporocysts ellipsoidal, $8.8 \times 5.4(8.0$ $9.6 \times 4.8-6.4) \mathrm{n}=10$; SI $=1.6(1.43-1.83)$. Stieda and substieda body present. Sporocyst residuum present, composed of few (5-10) granules arranged near centre of sporocyst.

Type host: Phelsuma rosagularis Vinson et Vinson, 1969, the Mauritius upland forest gecko (Sauria: Gekkonidae). Adult male collected 21st October, 1995.

Type locality: Brise Fer Mountain, Black River Gorges National Park, Mauritius $\left(20^{\circ} 22^{\prime} 30^{\prime \prime} \mathrm{S}, 57^{\circ} 25^{\prime} 42^{\prime \prime} \mathrm{E}\right)$.

Site of infection: Unknown; oocysts recovered from faeces.

Prevalence: Two of four individuals. All five of the new species described in this paper were isolated from a single individual.

Type material: Photosyntype deposited at the Pathology Museum of the Institute of Zoology, Zoological Society of London, Regent's Park NWI 4RY, UK (Acc. No. ZSL006).

Etymology: The specific name is given in honour of Dr. Mary Corliss Pearl, behavioural ecologist and conservation biologist, who has devoted her life to the conservation of biodiversity and preservation of ecosystem health around the world.
Remarks. The oocysts of Isospora pearlae differ from I. cottinghamae in the consistent presence of a single wall, the consistently more elongate shape, lack of overlap in size ranges, consistently smaller size, and from the three Isospora spp. previously described from geckoes of the genus Phelsuma (see remarks under I. cottinghamae). Note that the ranges of the sporocyst and oocyst widths and lengths do not form a continuum with those of $I$. cottinghamae, and are distinct when presented as a scattergram of individual oocyst lengths vs. widths (data not shown). Among other species of Isospora from the Gekkonidae, oocysts of I. schlegeli Upton, Hanley, Case et McAllister, 1991 are sub-spheroidal, have only minimal overlap in width with I. pearlae, have a bilayered wall and ovoidal sporocysts $(\mathrm{SI}=1.33)$ which do not overlap in width range with $I$. pearlae (Upton et al. 1991). Oocysts of I. pearlae are distinguished from all other previously described Isospora of geckoes by their size and shape.

\section{Eimeria hartleyi sp. n.}

Figs. 7, 14

Description: Oocysts sub-spheroidal to ellipsoidal, $18.2 \pm 1.4 \times 14.5 \pm 0.7(16.0-20.8 \times 13.6-16.0), \mathrm{n}=10$; $\mathrm{SI}=1.26(1.18-1.33)$ Single-layered wall approximately 0.8 thick. Micropyle and oocyst residuum absent, 1-3 small polar granules present. Sporocysts ellipsoidal-cylindroidal, $10.5 \times 5.5(9.7-11.4 \times 5.0-6.3) \mathrm{n}=20 ; \mathrm{SI}=1.9$ (1.56-2.1). Stieda body absent. Compact sporocyst residuum present, composed of spheroidal cluster of globular material. Sporocysts appear to taper more abruptly at one end.

Type host: Phelsuma cepediana Merrem, 1820, the bluetailed day gecko (Sauria: Gekkonidae). Adult (sex not recorded) collected 22nd October, 1995.

Type locality: In a traveller's palm near Mauritius Wildlife Fund lodge, Brise Fer Mountain, Black River Gorges National Park, Mauritius $\left(20^{\circ} 22^{\prime} 27^{\prime \prime} \mathrm{S}, 57^{\circ} 25^{\prime} 48^{\prime \prime} \mathrm{E}\right)$.

Site of infection: Unknown; oocysts recovered from faeces.

Prevalence: Faeces from a single individual were examined and found to contain these oocysts.

Type material: Photosyntype deposited at the Pathology Museum of the Institute of Zoology, Zoological Society of London, Regent's Park NWI 4RY, UK (Acc. No. ZSL007).

Etymology: The specific name is given to honour John R.M. Hartley, Former International Program Director at Durrell Wildlife Conservation Trust, whose enthusiasm for conservation of Mauritian endemic species has ensured the continued support of the international conservation community.

Remarks. Oocysts of E. hartleyi differ in their shape and dimensions, and in those of their sporocysts, from those of the other eimerians described in this paper. Among the Eimeria known to infect geckoes of the genus Phelsuma, oocysts of E. phelsumae are cylindroidal, and those of E. brygooi and E. simonkingi are spheroidal to sub-spheroidal with no overlap in width ranges, both 
have a bilayered wall, and contain less ellipsoidal oocysts. In addition, sporocysts of E. brygooi do not overlap in width range and oocysts of E. brygooi have no polar granules (Upton and Barnard 1987, Ball and Daszak 1995). Of other Eimeria species that infect geckoes, oocysts of E. gekkonis Tanabe, 1928 from Gekko japonicus in Tokyo are ovoidal, contain ovoidal sporocysts with tapered ends, probably have a bilayered wall (described as surrounded by three membranes) and possibly a micropyle (Tanabe 1928). Oocysts of E. hemidactyli from Hemidactylus flaviviridis in India are lemon-shaped (Knowles and Das Gupta 1935). Oocysts of E. tarentolae from Tarentola mauritanica have small spheroidal sporocysts, a bilayered oocyst wall and lack a polar granule (Matuschka and Bannert 1986). Oocysts of E. furmani Upton, Freed, Burdick et McAllister, 1990 from Hemidactylus frenatus in Madagascar are larger than E. hartleyi, have a bilayered wall, contain polar granules only rarely and have ellipsoidal sporocysts that do not overlap in width range with those of E. hartleyi (Upton et al. 1990). Oocysts of Eimeria helenae Bray, 1984 from Hemidactylus brookei are larger, more ellipsoidal $(\mathrm{SI}=1.5)$, overlap minimally in length range with those of $E$. hartleyi and contain nearly spheroidal sporocysts (Bray 1984). The oocysts of E. hartleyi differ from those of all other Eimeria spp. described from the family Gekkonidae in size and shape.

\section{Unidentified coccidian}

Fig. 8

Here we report on the finding of what appear to be tetrazoic oocysts or sporocysts of an unidentified coccidian, in the faeces of a Phelsuma cepediana gecko.

Description: Tetrazoic oocysts or sporocysts spheroidal to sub-spheroidal $10.2 \times 8.5(9.9-10.4 \times 8-9), \mathrm{n}=2$; $\mathrm{SI}=1.2(1.1-1.3)$.

H o s t: Phelsuma cepediana Merrem, 1820, the blue-tailed day gecko (Sauria: Gekkonidae).

Site of infection: Unknown; oocysts/sporocysts recovered from faeces.

L o c a lity: In a traveller's palm near Mauritius Wildlife Fund lodge, Brise Fer Mountain, Black River Gorges National Park, Mauritius $\left(20^{\circ} 22^{\prime} 27^{\prime \prime} \mathrm{S}, 5^{\circ} 025^{\prime} 48^{\prime \prime} \mathrm{E}\right)$.

Prevalence: Unknown, this faecal sample was pooled from seven individuals housed as a single species group for 14 days in captivity in Mauritius.

Remarks. In the absence of a large number of measurements, and information on the endogenous stages, the identity of these oocysts is unknown. It is possible that they are sporocysts of an unknown Sarcocystis sp., as has been reported previously (Upton and Barnard 1987). However, no Sarcocystis oocysts have been observed in any of the $P$. cepediana faecal samples examined here, or in over 1600 faecal samples of other wild-caught Mascarene lizards examined in two previous studies (Daszak 1995, Leinwand et al. 2005). It is also possible that this represents an undescribed species of Cryptosporidium.
However, of the three species of Cryptosporidium described from reptiles, the oocysts of $C$. serpentis Levine, 1980 and C. varanii Pavlásek, Lávičková, Horák, Král et Král, 1995 (syn. C. saurophilum Koudela et Modrý, 1998) are significantly smaller than those reported here (Upton et al. 1989, Tilley et al. 1990, Cranfield and Graczyk 1994, Koudela and Modrý 1998), and only C. lampropeltis Anderson, Duszynski et Marquardt, 1968 is of similar size. All other reports of Cryptosporidium sp. from reptiles, including one from Phelsuma madagascariensis grandis, are of significantly smaller oocysts (Upton and Barnard 1987, Paperna 2001, Terrell et al. 2003). The large number of sporocysts seen in the current sample, and their large size suggest that their most likely identity is an unidentified adeleid coccidian from an invertebrate host ingested by the reptile. This phenomenon has been described previously (Berto et al. 2008) and has been the source of previous misidentifications.

\section{DISCUSSION}

The finding of five new species in a single individual of a Phelsuma gecko is striking, and suggests that there may be a large diversity of reptile coccidians remaining to be described. This host genus is diverse, and ancient, with diversification following the formation of islands in the Indian Ocean over the last 7 million years $(\mathrm{McD}$ ougall and Chamalaun 1969, Austin et al. 2004). It is likely that the eimerian parasites of these geckoes have followed in this radiation and it is therefore not surprising that $P$. rosagularis harbours a diverse range of coccidia. It is also likely that the diversity of coccidia in $P$. cepediana and other hosts within the genus is equally high, and further work on coccidia of these reptiles will likely result in a large number of new species.

The genus Phelsuma has been subject to the same environmental pressures that caused the extinction of other more well-known species such as the dodo, Raphus cucullatus L. (Vaughan and Wiehe 1941, Cheke 1987, Jones and Hartley 1995). All Phelsuma spp. from Mauritius are listed on Schedule 2 of CITES (http://www.iucn.org/ themes/sse/programs/cites/cites.htm) which restricts their international trade and one of them, $P$. guentheri, is listed as "Endangered" on the IUCN redlist (http://www.iucnredlist.org/). Recent papers have highlighted the threat which some infectious diseases represent to wildlife populations (Daszak and Cunningham 1999, Daszak et al. 2000). However, it is unlikely that the parasites described in this paper are a significant threat to the conservation of $P$. rosagularis or $P$. cepediana in the wild. There is little evidence that Eimeria or Isospora spp. infections represent a disease threat to wild populations of lizards, despite their often continually high prevalence in wild populations (Daszak 1995). However there are reports of coccidiosis outbreaks in captive reptiles and coccidian parasites may become a problem in captive breeding programmes for these endangered geckoes (Modrý and Koudela 1998). 
Acknowledgements. Fieldwork was funded by Fauna and Flora International, The Royal Geographical Society, the Percy Sladen Memorial Fund, The Appleyard Fund, Leica Cameras and Kodak, UK. We are grateful to the Mauritius Government National Parks and Conservation Service (Director, Y. Mungroo) for fieldwork and export permits, and to Kirsty Swinnerton and Pierre de Boucherville Baissac of the Mauritius Project of the Durrell Wildlife Conservation Trust (formerly the Jersey Wildlife Preservation Trust) for logistical support. Dr. John G.E, Lewis, Sheila Lewis, Dr. Janet D. Cottingham, Dr. Ralph Manly
(Kingston University), Martin Webster and Esther Wenman assisted in collection of host animals, or with logistics or laboratory support. Simon Tonge, Paul Pearce-Kelly, David Clarke and Elspeth Chaplin (Zoological Society of London, London, UK), John Hartley and Quentin Bloxam (Durrell Wildlife Conservation Trust, Jersey, Channel Islands, UK), Drs. Steve North and David Bullock assisted in planning fieldwork. Dr. Nick Arnold (The Natural History Museum, London, UK) and Dr. Jeremy J. Austin (Museum Victoria, Melbourne, Australia) provided advice on host taxonomy.

\section{REFERENCES}

Anderson D.R., Duszynski D.W., Marquardt W.C. 1968: Three new coccidia (Protozoa: Telosporea) from kingsnakes, Lampropeltis spp., in Illinois, with a redescription of Eimeria zamenis Phisalix, 1921. J. Parasitol. 54: 577-581.

Austin J.J., Arnold E.N., Jones C.G. 2004: Reconstructing an island radiation using ancient and recent DNA: the extinct and living day geckos (Phelsuma) of the Mascarene islands. Mol. Phylogenet. Evol. 31: 109-122.

Ball S.J., Daszak P. 1995: Description of the oocysts of three new species of Eimeria (Apicomplexa, Eimeriidae) from geckoes (Sauria, Gekkonidae). Syst. Parasitol. 32: 101-106.

Berto B.P., Lopes B.D.B., Flausino W., Teixeira W.L., Lopes C.W.G. 2008: Contribution on the study of Isospora hemidactyli Carini, 1936 and a report of an adeleid pseudoparasite of the house gecko Hemidactylus mabouia, from the Rio de Janeiro Metropolitan Region, Brazil. Rev. Bras. Parasitol. Vet. 17: $150-154$.

Bhatia B.L. 1936: Coccidia of lizards. Curr. Sci. 5: 177-178.

Bovee E.C. 1971: New species of Eimeria from lizards of Japan. Trans. Am. Microsc. Soc. 90: 336-343.

BraY R.S. 1984: Some parasitic protozoa from the Gambia. J. Protozool. 31: 577-578.

Brownstein D.G., Stranberg J.D., Montali R.J., Bush M., ForTner J. 1977: Cryptosporidium in snakes with hypertrophic gastritis. Vet. Pathol. 14: 606-617.

CARINI A. 1936: Sur une Isospora de l'intestin de l'Hemidactylus mabujae. Ann. Parasitol. Hum. Comp. 14: 444-446.

Chene A.S. 1987: An ecological history of the Mascarene Islands, with particular reference to extinctions and introductions of land vertebrates. In: A.W. Diamond (Ed.), Studies of Mascarene Island Birds. Cambridge University Press, Cambridge, UK, pp. 5-90.

Cranfield M.R., GraczyK T.K. 1994: Experimental infection of elaphid snakes with Cryptosporidium serpentis (Apicomplexa: Cryptosporidiidae). J. Parasitol. 80: 823-826.

DASZAK P. 1995: Prevalence of endoparasites in Round Island reptiles. Herpetol. J. 5: 195-199.

Daszak P., Ball S.J. 1991: Five new species of Eimeria (Apicomplexa, Eimeriidae) from lizards. Syst. Parasitol. 20: 141-147.

Daszak P., Cunningham A.A. 1999: Extinction by infection. Trends Ecol. Evol. 14: 279.

Daszak P., Cunningham A.A., Hyatt A.D. 2000: Emerging infectious diseases of wildlife - threats to biodiversity and human health. Science 287: 443-449.

DuszYnski D.W. 1999: Revisiting the code: clarifying namebearing type for photomicrographs of Protozoa. J. Parasitol. 85: 769-770.

Else J.G., Colley F.C. 1975: Eimeria cicaki sp. n. and Isospora thavari sp. n. from the house lizard Gehyra mutilata Boulenger in Malaysia. J. Protozool. 22: 455-457.
Finkelman S., Paperna I. 2002: The endogenous development of four new species of Isospora Schneider, 1881 (Apicomplexa: Eimeriidae) from Australian geckoes. Syst. Parasitol. 51: 59-71.

Frey J.K., Yates T.L., Duszynski D.W., Gannon W.L., Gardner S.L. 1992: Designation and curatorial management of type host specimens (symbiotypes) for parasitic species. J. Parasitol. 78: 930-932.

Jirkư M., Modrý D., Šlapeta J.R., Koudela B., Lukeš J. 2002: The phylogeny of Goussia and Choleoeimeria (Apicomplexa; Eimeriorina) and the evolution of excystation structures in coccidia. Protist 153: 379-390.

Jones C.G., Hartley J. 1995: A conservation project on Mauritius and Rodrigues: an overview and bibliography. Dodo: J. Jersey Wildl. Pres. Trusts 9: 40-65.

Knowles R., Das Gupta B.M. 1935: The coccidia of lizards. Indian J. Med. Res. 22: 701-707.

Koudela B., Modrý D. 1998: New species of Cryptosporidium (Apicomplexa: Cryptosporidiidae) from lizards. Folia Parasitol. 45: 93-100.

Leinwand I., Kilpatrick A.M., Cole N., Jones C.G., Daszak P. 2005: Patterns of coccidial prevalence in lizards of Mauritius. J. Parasitol. 91: 1103-1108.

LeVine N.D. 1980: Some corrections of coccidian (Apicomplexa: Protozoa) nomenclature. J. Parasitol. 66: 830-834.

MatuschKa F.-R., Bannert B. 1986: Eimeria tarentolae n. sp. from the Moorish gecko, Tarentola mauritanica. J. Protozool. 33: 309-311.

McAllister C.T., Upton S.J. 1989: Redescription of Eimeria boveroi (Apicomplexa, Eimeriidae) from Hemidactylus mabouia (Sauria, Gekkonidae), and a new host record for Eimeria sceloporis. Trans. Am. Microsc. Soc. 108: 92-95.

McAllister C.T., Upton S.J., Freed P.S. 1988: Eimeria lineri sp. n. (Apicomplexa, Eimeriidae) from the Mediterranean gecko, Hemidactylus turcicus (Sauria, Gekkonidae), in Louisiana and Texas. Proc. Helminthol. Soc. Wash. 55: 256-259.

McDougall I., Chamalaun F.H. 1969: Isotopic dating and geomagnetic polarity studies on volcanic rocks from Mauritius, Indian Ocean. Geol. Soc. Am. Bull. 80: 1419-1442.

Modrý D., JiRkŮ M. 2006: Three new species of coccidia (Apicomplexa: Eimeriorina) from the Marble-throated skink, Marmorosphax tricolor Bavay, 1869 (Reptilia: Scincidae), endemic to New Caledonia with a taxonomic revision of Eimeria spp. from scincid hosts. Parasitol. Res. 99: 416-428.

Modrý D., Koudela B. 1998: Isosporan infections of Chamaeleo calyptratus represent growing problem for its breeding in captivity. Reptile Amphib. Mag. 54: 38-41.

Modrý D., Koudela B., Volf J. 1997: Four new species of Isospora Schneider, 1881 (Apicomplexa: Eimeriidae) from reptiles from the islands of Seychelles. Syst. Parasitol. 37: 73-78. 
PAPERNA I. 2001: Cryptosporidium sp. in a free ranging house gecko (Hemidactylus turcicus) in Israel. Parassitologia 43: 91-93.

Paperna I., Landsberg J.H. 1989: Description and taxonomic discussion of eimerian coccidia from African and Levantine geckoes. S. Afr. J. Zool. 24: 345-355.

Peirce M.A. 1984: Some parasites of reptiles from Zambia and Indian Ocean islands with a description of Haemogregarina zambiensis sp. nov. from Dispholidus typhus. J. Nat. Hist. 18: 211-217.

TANABE M. 1928: Eimeria gekkonis sp. n., a new coccidian from the gecko, Gekko japonicus (Dumeril et Bibron). Acta Med. Keijo 11: 207-220.

Terrell S.P., Uhl E.W., Funk R.S. 2003: Proliferative enteritis in leopard geckos (Eublepharis macularius) associated with Cryptosporidium sp. infection. J. Zoo Wildl. Med. 34: 69-75.

Tilley M., Upton S.J., Freed P.S. 1990: A comparative study on the biology of Cryptosporidium serpentis and Cryptosporidium parvum (Apicomplexa, Cryptosporidiidae). J. Zoo Wildl. Med. 21: 463-467.

Upton S.J., Barnard S.M. 1987: Two new species of coccidia (Apicomplexa: Eimeriidae) from Madagascar gekkonids. J. Protozool. 34: 452-454.

Upton S.J., Freed P.S., Burdick D.A. 1992a: Description of the oocysts of three new species of coccidia (Apicomplexa, Eimeriidae) from lizards in Namibia. Syst. Parasitol. 22: 33-37.

Received 16 March 2009
Upton S.J., Freed P.S., Burdick D.A., McAllister C.T. 1990: Seven new species of coccidia (Apicomplexa, Eimeriorina) from reptiles in Madagascar. Can. J. Zool. 68: 2368-2375.

Upton S.J., Freed P.S., Freed D.A. 1992b: Two new species of Caryospora (Apicomplexa) from snakes in Cameroon, with redescriptions of two coccidians from Hemidactylus mabouia (Gekkonidae). Syst. Parasitol. 23: 135-140.

Upton S.J., Hanley K., Case T.J., McAllister C.T. 1991: Description of Isospora schlegeli sp. nov. (Apicomplexa, Eimeriidae) from gekkonid lizards in the South Pacific. Can. J. Zool. 69: 3108-3110.

Upton S.J., McAllister C.T., Freed P.S., Barnard S.M. 1989: Cryptosporidium spp. in wild and captive reptiles. J. Wildl. Dis. 25: 20-30.

Vaughan R.E., Wiehe P.O. 1941: Studies on the vegetation of Mauritius. 3. The structure and development of the upland climax forest. J. Ecol. 29: 127-160.

VINSON J., VINSON J.-M. 1969: The saurian fauna of the Mascarene Islands 1. A revision of the fauna. Bull. Mauritius Inst. 6: 203320.

Yамамото K. 1933: Studien über die Kokzidien. Fukuoka Acta Med. 26: 40-43.

Accepted 6 October 2009 